\author{
Пчелянська Г.Б. \\ старший викладач \\ кафедра обліку та аудиту \\ Одеська національна академія харчових \\ технологій \\ вул. Канатна, 112, м. Одеса, Україна, 65039 \\ E-mail: gaya_od@ukr.net
}

\author{
Васьковська К.О. \\ кандидат економічних наук, старший викладач \\ кафедра обліку та аудиту \\ Одеська національна академія харчових \\ технологій \\ вул. Канатна, 112, м. Одеса, Україна, 65039 \\ E-mail:v.caterin17@gmail.com
}

Пчелянський Д.П.

студент 3 курсу Інституту комп'ютерних систем

Одеський національний політехнічний університет

пр-т Шевченка, 1, м. Одеса, Україна, 65044

E-mail: d.pchelyanskiy97z@gmail.com

\title{
РОЛЬ ІНФОРМАЦІЙНИХ ТЕХНОЛОГІЙ В УПРАВЛІННІ ПІДПРИЄМСТВОМ
}

У статті досліджено роль інформаційних технологій в управлінні підприємством, розкрито сутність та перспективи впровадження інформаційних технологій в управлінні сучасними підприємствами. Відображено тенденції впровадження інформаційних технологій у виробничу діяльність підприємства. Розглянуто концепції управління підприємством з використанням інформаційних технологій. Проаналізовані як переваги так і недоліки застосування інформаційних технологій в процесі прийняття управлінських рішень. Рекомендовано запровадження інформаційних технологій в управлінні підприємством, що дозволить забезпечити безперервний облік та контроль ресурсів на підприємстві, оперативну підготовку аналітичних документів, прогнозування показників діяльності підприємства, підвищення ефективності прийняття управлінських рішень.

Ключові слова: інформація, інформаційні технології, управлінське рішення, інтегроване інформаційне середовище, система підтримки прийняття рішень, бізнес-процес, управління підприємством.

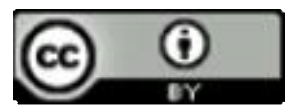

This work is licensed under a Creative Commons Attribution 4.0 International License http://creativecommons.org/licenses/by/4.0/
Постановка проблеми та її зв'язок з важливими науковими та практичними завданнями. Сучасне підприємство - складна соціальноекономічна система, для керування якої потрібні нові форми і методи управління. Впровадження інформаційних технологій стає одним із інструментів підвищення якості системи управління підприємством.

Інформаційні технології є частиною життєдіяльності всіх сфер суспільства та всіх галузей економіки країни. Впродовж останнього десятиріччя інформаційні технології все більше проникали в бізнес: це системи автоматизованого проектування і програми фінансового, податкового та управлінського обліку. Тому питання використання сучасних інформаційних систем і технологій, їх переваги та недоліки залишаються актуальними.

Аналіз останніх публікацій по проблемі. Незважаючи на досить широке висвітлювання у роботах актуальності впровадження інформаційних технологій, їх ролі, перспектив, не достатньо уваги надається проблемам, які існують у підприємств в цьому напрямку, конкретним крокам щодо впровадження сучасних інформаційних технологій у виробничу діяльність.
Проблема використання інформаційних технологій в управлінні підприємством знайшла своє відображення в працях багатьох зарубіжних та вітчизняних вчених, таких як: Мейора Т., Стікула І., Коберна А., Македонського М., Матвєєва М., Петрова Ю., Бутинця Ф.Ф., Ковальчука Т.М., Пушкаря М.С. Проте дослідження розвитку інформаційних технологій в управлінні підприємством стають все більш актуальними.

Формулювання цілей дослідження. Мета статті - дослідження основних напрямків використання інформаційних технологій для оптимізації діяльності підприємства, відображення тенденцій впровадження інформаційних технологій у виробничу діяльність підприємств. Поширення інноваційних інформаційних технологій стають вирішальними чинниками трансформації в управлінні підприємством, які ще недостатньо вивчені.

Виклад основних результатів та їх обгрунтування. Однією 3 найважливіших проблем для керівників підприємства $€$ використання інформаційних технологій в розробці управлінських рішень. У гострій конкуренції досягають успіху підприємства, в яких керівництво приймає ефективні рішення, вико- 
ристовуючи можливості сучасних інформаційних технологій.

Проблеми використання інформаційних технологій в прийнятті управлінських рішень на підприємстві розглянуто в працях як вітчизняних, так і зарубіжних фахівців з управління. Багато питань залишається нерозкритими і потребують поглибленої розробки теоретичних і методологічних аспектів щодо впровадження ефективного інформаційного забезпечення управління на підприємстві.

Для реалізації поставленої мети необхідно вирішити такі завдання:

- висвітлити основні напрямки у формуванні інформаційних технологій для прийняття управлінських рішень;

- обгрунтувати доцільність впровадження інформаційних комп'ютерних систем управління підприємством;

- запропонувати алгоритми вирішення проблем вибору інформаційних комп'ютерних технологій в управлінні підприємством.

Інформаційні технології (IT) - це комплекс програмно-технічних засобів і методів виробництва, передачі, обробки та споживання інформації. Їх впровадження $є$ створення системи, у якій інформаційні потоки налагоджені таким чином, що користувачі 3 мінімальними витратами отримують доступ до необхідної інформації в реальному часі [2].

Впровадження інформаційних технологій $€$ інструментом, що дозволяє підвищити ефективність управління підприємством на базі створення єдиного інформаційного простору, яке містить інформацію про швидкі зміни потреб ринку, конкурентоспроможність продукції підприємства, його виробничі можливості, заходи контролю за виконанням планів, економією ресурсів [9].

Аналіз еволюції розвитку інформаційних технологій управління показав 3 одного боку, стрімкий ріст об'ємів інформації, необхідної для прийняття

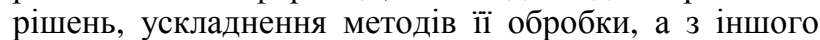
боку, вражаючі досягнення в галузі комп'ютерної техніки, периферійної апаратури, пристроїв передачі даних та телекомунікацій.

Саме такі фактори обумовили зародження i розвиток нового покоління IT менеджменту - системи підтримки прийняття рішень (СППР).

Створення інформаційно-аналітичної бази моделей СППР дозволила б оснастити менеджерів інструментарієм необхідним для вирішення широкого кола завдань управління. СППР повинна включати моделі, які мають бути адаптовані до проблем управління підприємствами конкретної галузі, яка б дозволила:

- прискорити процес знаходження найбільш доцільних рішень;

- прогнозувати ефективність випуску продукції в середньо- та короткотерміновій перспективі;

- проводити оцінку прибутковості (або збитковості) виробництва продукції при змінах основних економічних факторів;

- запобігати прийняттю нераціональних рішень..

Виділяють такі етапи впровадження нових інформаційних технологій в управлінні підприємством:

- Інтернет, спеціалізовані глобальні мережі;

- мейнфрейми;

- глобальні соціальні мережі;

- хмарні обчислення та Internet-сенсори.

Одним з найбільш перспективних технологій $€$ хостингові та "хмарні" технології. Ці новації дозволяють економити фінанси за рахунок скорочення капітальних інвестицій. Актуальність полягає у тому, що в останній час все більше підприємств намагаються мінімізувати інвестиції в розвиток своєї інфраструктури.

Для вітчизняного бізнесу популярною є технологія HANA (High Performance Analytic Appliance), яка обробляє великі масиви інформації.

Інформаційні технології дають можливість управляти бізнесом незалежно від місцезнаходження. Деякі інструменти - "Банк-Клієнт online" і система електронної звітності - дозволяють ефективніше вирішувати цілий ряд питань, пов'язаний з життєдіяльністю підприємства. Всі інші інструменти (сайт, соціальні мережі, Internet-спільноти, "Skype") відкривають для бізнесу можливості, які без цих технологій були б просто недоступні: сьогодні можна успішно працювати $з$ клієнтами не тільки в крупних містах, а i по всій країні, а також за кордоном. Це стало можливо завдяки комплексному використанню технологій.

Слід відзначити, що поряд 3 перевагами використання інформаційних технологій на підприємствах різних галузей існують і недоліки (табл.1).

Таблиця 1

Переваги та недоліки використання інформаційних систем і технологій в життедіяльності підприємства [4]

\begin{tabular}{|c|c|}
\hline Переваги & Недоліки \\
\hline $\begin{array}{l}\text { Облікові дані реєструються та зберігаються в єдиній інформацій- } \\
\text { ній базі. }\end{array}$ & \multirow{2}{*}{$\begin{array}{l}\text { Статичність, оновлення техніки, на- } \\
\text { вчання персоналу, висока ціна [7]. } \\
\text { Зростання кіберзлочинності [3]. }\end{array}$} \\
\hline $\begin{array}{l}\text { Швидкий доступ до інформації для прийняття управлінських рі- } \\
\text { шень. }\end{array}$ & \\
\hline Великі можливості для планування діяльністю підприємства. & \multirow{2}{*}{ Залежність від мережі Інтернет. } \\
\hline Можливість постійного ведення оперативного контролю. & \\
\hline Можливість доступу до інформації через мережу Інтернет. & $\begin{array}{l}\text { Обмін інформацією через Інтернет ро- } \\
\text { бить ці відомості і бізнес в цілому } \\
\text { більш уразливими. }\end{array}$ \\
\hline
\end{tabular}


Використання переваг сучасних інформаційних технологій може забезпечити успіх підприємства, оскільки це нове бачення інформаційних, новий підхід до методів, процедур управління.

Висновки та перспективи подальших досліджень. Інформаційні технології стають все більше доступними та незамінними в функціонуванні управлінських процесів. Комп'ютерні інформаційні технології розвиваються та дають поштовх у розвитку економічних і управлінських інформаційних технологій, набуваючи все більшої значущості як найважливіший інструмент науково-технічного та соціально- економічного розвитку суспільства. Отже, освоєння сучасних інформаційних технологій суттєво підвищує якість прийняття управлінських рішень.

Таким чином, інформаційні технології дозволяють підвищити ефективність функціонування підприємства в результаті створення нових можливостей в управлінні. 3 аналізу наукових джерел 3 досвіду впровадження IT звісно, що впровадження інформаційних технологій призводить до зміни форм і методів управління підприємством, до створення нової організаційної структури управління.

\section{Література}

1. Іовчева А. М. Інформаційне суспільство в умовах глобалізаційного розвитку / А. М. Іовчева // Наукові праці [Чорноморського державного університету імені Петра Могили комплексу "Києво-Могилянська академія"]. Сер. : Політологія. - 2014. - Т. 236, Вип. 224. - С. 108-111.

2. Кривов'язюк І. В. Проблеми запровадження інформаційних технологій в управлінні логістичною системою підприємства / І. В. Кривов’язюк, Ю. М. Кулик // Актуальні проблеми економіки. - 2013. - № 12. - С. 83-90.

3. Луценко В. М. Особливості системи контролю інформації потоків великого розміру // В. М. Луценко, А. М. Балан // Захист інформації. - 2013 - №3. - С.231-235.

4. Маркова Т. Д. Особливості використання інформаційних систем і технологій в системі обліку та контролю / Т. Д. Маркова, Г. Б. Пчелянська // Економіка харчової промисловості. - 2016. - Т. 8, Вип. 3. - С.40-45; DOI: 10.15673/fie.v8i3.207

5. Петрухно Ю. С. Інформаційне суспільство: поняття, основні складові, характеристика / Ю. С. Петрухно // Вісник Одеського національного університету. Сер. : Бібліотекознавство. Бібліографознавство. Книгознавство. - 2014. - Т. 19, Вип. 1. - С. 127-133.

6. Тітова О. П. Особливості та переваги використання новітніх інформаційних технологій в управлінні агрохолдингу «Укрлендфармін» / О. П. Тітова // Вісник Житомирського національного агроекологічного університету. - 2012. - № 2(2). - С. 90-96.

7. Ткаль Я. С. Особливості використання інформаційних систем і технологій обліку / Я. С. Ткаль // Вісник Бердянського університету менеджменту і бізнесу - 2014. - № 2 (26). - С.127-130.

8. Янчук Т. В. Алгоритм впровадження інформаційних технологій в сучасний бізнес / Т. В. Янчук // Науковий вісник Херсонського державного університету. Серія «Економічні науки». - 2014. - Вип. 5, Част. 3. - С. $128-130$.

9. Яцюк С. Особливості методики викладання інформаційних систем і технологій для студентівменеджерів / С. Яцюк // Науковий вісник Східноєвропейського національного університету імені Лесі Українки. Педагогічні науки. - 2013. - № 7. - С. 92-95.

10. Информатизация предприятия: преимущества и недостатки [Електронний ресурс]. - Режим доступу: http://economyz.ru/informatsionnye-tekhnologii-v-biznese/

Пчелянская Г.Б.

старший преподаватель

кафедра учета и аудита

Одесская национальная академия пищевых технологий

ул. Канатная, 112, г. Одесса, Украина, 65039 E-mail: gaya od@ukr.net
Васьковская Е.А.

кандидат экономических наук, старший преподаватель кафедра учета и аудита

Одесская национальная академия пищевых технологий

ул. Канатная, 112, г. Одесса, Украина, 65039 E-mail: v.caterin17@gmail.com

Пчелянский Д.П.

студент 3 курса Института компьютерных систем

Одесский национальный политехнический университет

пр-т Шевченко, 1 г. Одесса, Украина, 65044

E-mail: d.pchelyanskiy97z@gmail.com

\section{РОЛЬ ИНФОРМАЦИОННЫХ ТЕХНОЛОГИЙ В УПРАВЛЕНИИ ПРЕДПРИЯТИЕМ}

Целью исследования является освещение и анализ теоретических и практических аспектов применения информационных технологий в управлении предприятием. В статье рассматривается 
роль информационных технологий в управлении предприятием, раскрыта сущность и перспективы внедрения информационных технологий в управлении современным предприятиям. Дано определение информационных технологий, определен перечень преимуществ использования информационных технологий в управлении предприятием. Отражены тенденции внедрения информационных технологий в производственную деятельность предприятий. Рассмотрены концепции управления предприятием с использованием информационных технологий.

Внедрение информационных технологий в управлении предприятием обеспечивает ускорение обработки информации, сокращение управленческого персонала, обеспечение качественной информации руководства, позволяет своевременно и качественно осуществлять диагностику хозяйственной деятельности, повышает скорость принятия управленческих решений.

Проанализированы преимущества и недостатки применения информационных технологий в процессе принятия управленческих решений на предприятии. Определено эффективность применения информационных технологий в процессе принятия управленческих решений. Развитие информационных технологий и их интеграция со сферой управления и экономики предприятия будет способствовать оптимальному развитию предприятий.

Дальнейшие исследования в данном направлении должны быть направлены на создание универсальной модели информационной технологии, которая позволит значительно повысить эффективность управления деятельностью предприятия.

Ключевые слова: информация, информационные технологии, управленческое решение, интегрированное информационное пространство, система поддержки принятия решений, бизнеспроцесс, управление предприятием.

Pchelianska H. Assistant

Department of Accounting and Auditing Odesa National Academy of Food Technologies

Kanatna str., 112, Odesa, Ukraine, 65039 E-mail: gaya_od@ukr.net
Vaskovska K.

Ph. D., Assistant

Department of Accounting and Auditing

Odesa National Academy of Food Technologies

Kanatna str., 112, Odesa, Ukraine, 65039

E-mail:v.caterin17@gmail.com

Pcheliansky D.

The student of the third grade of Institute of Computer Systems

Odesa National Technical University

Shevchenko, Ave. 1, Odesa, Ukraine, 65044

E-mail: d.pchelyanskiy97z@gmail.com

\section{THE ROLE OF INFORMATION TECHNOLOGIES IN THE MANAGEMENT OF THE ENTERPRISE}

The purpose of this study is to highlight and analyze the theoretical and practical aspects of the application of information technologies in enterprise management. The article explores the role of information technologies in enterprise management, reveals the essence and prospects of introducing information technologies in the management of modern enterprises. The definition of information technologies has been given, the list of advantages of using information technologies in enterprise management has been defined. The tendencies of introduction of information technologies in the production activity of enterprises have been reflected. The concepts of enterprise management with the use of information technologies have been considered. The introduction of information technologies in enterprise management accelerates the processing of information, reduces management personnel, provides qualitative management information, allows timely and qualitatively conduct diagnostics of economic activities, increases the speed of management decisions. The advantages and disadvantages of using information technologies in the process of making managerial decisions at the enterprise have been analyzed. The effectiveness of the use of information technologies in the process of making managerial decisions has been determined. The development of information technologies and their integration with the sphere of management and the economy of the enterprise will contribute to the optimal development of enterprises. Further research in this direction should be aimed at creating a universal model of information technologies that will significantly improve the efficiency of enterprise management.

Key words: information, information technologies, management solution, integrated information space, decision support system, business process, enterprise management. 


\section{References}

1. Iovcheva, A. M. (2014). Informatsiine suspilstvo v umovakh hlobalizatsiinoho rozvytku. Naukovi Pratsi Chornomorskoho Derzhavnoho Universytetu Imeni Petra Mohyly Kompleksu "Kyievo-Mohylianska Akademiia", 236(224), politolohiia, 108-111.

2. Kryvov'iaziuk, I. V., \& Kulyk, Yu. M. (2013). Problemy zaprovadzhennia informatsiinykh tekhnolohii v upravlinni lohistychnoiu systemoiu pidpryiemstva. Aktualni Problemy Ekonomiky, (12), 83-90.

3. Lutsenko, V. M., \& Balan, A. M. (2013). Osoblyvosti systemy kontroliu informatsii potokiv velykoho rozmiru. Zakhyst Informatsii, (3), 231-235.

4. Markova, T. D., \& Pchelianska, H. B. (2016). Osoblyvosti vykorystannia informatsiinykh system i tekhnolohii v systemi obliku ta kontroliu. Ekonomika Kharchovoi Promyslovosti,8(3), 40-45. doi:10.15673/fie.v8i3.207

5. Petrukhno, Yu. Ye. (2014). Informatsiine suspilstvo: Poniattia, osnovni skladovi, kharakterystyka. Visnyk Odeskoho Natsionalnoho Universytetu, 19(1), bibliotekoznavstvo. bibliohrafoznavstvo. knyhoznavstvo, 127-133.

6. Titova, O. P. (2012). Osoblyvosti ta perevahy vykorystannia novitnikh informatsiinykh tekhnolohii v upravlinni ahrokholdynhu «Ukrlendfarmin». Visnyk Zhytomyrskoho Natsionalnoho Ahroekolohichnoho Universytetu, (2 (2)), 90-96.

7. Tkal, Ya. S. (2014). Osoblyvosti vykorystannia informatsiinykh system i tekhnolohii obliku. Visnyk Berdianskoho Universytetu Menedzhmentu I Biznesu, (2 (26)), 127-130.

8. Yanchuk, T. V. (2014). Alhorytm vprovadzhennia informatsiinykh tekhnolohii v suchasnyi biznes. Naukovyi Visnyk Khersonskoho Derzhavnoho Universytetu, (5), 3 «ekonomichni nauky», 128-130.

9. Yatsiuk, S. (2013). Osoblyvosti metodyky vykladannia informatsiinykh system i tekhnolohii dlia studentivmenedzheriv. Naukovyi Visnyk Skhidnoievropeiskoho Natsionalnoho Universytetu Imeni Lesi Ukrainky, (7), pedahohichni nauky, 92-95.

10. Informatizatsiya predpriyatiya: Preimuschestva i nedostatki. Retrieved from http://economyz.ru/informatsionnye-tekhnologii-v-biznese/

Received 12 February 2018

Approved 26 February 2018

Available in Internet 31.03.2018 